\title{
ARAŞTIRMA/RESEARCH \\ Çukurova Üniversitesi sağlık bilimleri öğrencilerinin sağlıklı yaşam davranışları
}

\author{
Healthy life behaviors of the health science students of Cukurova University
}

Sevgi Özcan ${ }^{1}$, Ali Bozhüyük ${ }^{2}$

${ }^{1}$ Çukurova Üniversitesi Tip Fakültesi, Aile Hekimliği, Anabilim Dalı, Adana, Turkey

${ }^{2}$ Çiftlik Devlet Hastanesi, Niğde, Turkey

\section{Cukurova Medical Journal 2016;41(4):664-674.}

Abstract

Purpose: The aim of this study was to evaluate of health science students' healthy life behaviors.

Material and Methods: The sample population was composed of 801 students that attending to the health science schools (medicine, dentistry, midwifery, and nursery) of Cukurova University. The data was collected by an anonymous questionnaire and Health Promotion Lifestyle Profile-II scale (nutrition, physical activity, stress management, interpersonal relationships, spirituality, healthy responsibility).

Results: Of the $60 \%$ students were female. The mean age was $21.5 \pm 2.21(17-34)$ years. It is found that the mean score of Health Promotion Lifestyle Profile-II scale was a middle level (124.30 \pm 17.92$)$, the highest score was taken from spiritual growth subscale and the lowest one was taken from physical activity subscale. No significant relation was found between the age groups and the mean scores. Males got the higher score from the physical activity subscale, and females got the higher scores from all other subscales. The scores of the students attending to the medicine school were lower compared to the other fields.

Conclusion: Health science students are health professionals and role models of the future. It is considered that the results of our study may raise awareness and may be a guide for interventions to elevate these students' healthy life behaviors to a better level.

Key words: Healthy life behaviors, health sciences, students.

\section{GİRİŞ}

"Sağllı̆̆1 koruma ve geliştirme" denilince uzun bir süre insanların aklına ilk olarak doktorlar, hemşireler
Öz

Amaç: Bu çalışmanın amacı, sağlık bilimleri öğrencilerinin sağlıklı yaşam davranışlarının değerlendirilmesidir.

Gereç ve Yöntem: Araştırmanın örneklemini Çukurova Üniversitesi sağlık bilimleri bölümlerine (tıp, diş hekimliği, ebelik ve hemşirelik) devam eden 801 öğrenci olușturdu. Veriler, isimsiz olarak bir anket formu ve Sağlıklı Yaşam Biçimi Davranışları II ölçeği (beslenme, fiziksel aktivite, stres yönetimi, kişilerarası ilişkiler, tinsellik, sağlık sorumluluğu) ile toplandı.

Bulgular: Öğrencilerin \% 60' 1 kadındı. Yaş ortalaması 21,5 $\pm 2,21$ (17-34) yıldı. Sağlıklı Yaşam Biçimi Davranışları-II ölçeği puan ortalamasının orta düzeyde olduğu (124,30 $\pm 17,92)$, en yüksek puanın tinsellik, en düşük puanın fiziksel aktivite alt ölçeğinden alındığ saptandi. Yaş grupları ile ortalama puanlar arasında istatistiksel olarak anlamlı bir ilișki bulunmadı. Erkeklerin, fiziksel aktivite alt ölçeğinden, kadınların ise diğer bütün alt ölçeklerden daha yüksek puan aldıkları saptandı. Tip Fakültesi öğrencilerinin puanları, diğer fakülte ögrencilerininkinden daha düşüktü.

Sonuç: Sağlık bilimleri öğrencileri geleceğin sağlık profesyonelleri ve rol modelleridir. Calıșmamızın bulgularının farkındalık yaratacağı ve bu öğrencilerin sağlıklı yaşam davranışlarının daha iyi düzeye yükseltilmesi açısından yapılacak girişimler için yol gösterici olacağı düşünülmüş̧ür.

Anahtar kelimeler: Sağlıklı yaşam davranışları, sağlık bilimleri, ögrrenciler.

ve hastaneler gelmiș, ancak daha sonraları insanların sağlıklarının yaşam biçimlerine çok bağlı olduğu fark edilmeye başlanmıştır. Sağlıklı yaşam biçimi, bireyin sağlığını etkileyebilecek davranışlarını kontrol

Yazıșma Adresi/Address for Correspondence: Dr. Sevgi Özcan, Cukurova Üniversitesi Tıp Fakültesi Aile Hekimliği Anabilim Dalı, Adana, Turkey E-mail: sozcan@cu.edu.tr

Geliş tarihi/Received: 22.03.2016 Kabul tarihi/Accepted: 02.05.2016 
edebilmesi, günlük aktivitelerini düzenlerken kendi sağlık durumuna uygun davranışları seçmesi olarak tanımlanmaktadır. Günümüzde, egzersiz, beslenme, sigara içme ve stres gibi yaşam biçimi unsurlarının sağlığ1 ve kardiyovasküler hastalık riskini etkilediği; kanser, kalp hastalığ1, hipertansiyon ve diyabet gibi kronik hastalıklardaki morbidite ve mortalitenin yaşam biçimi değişiklikleri ile önemli ölçüde azaltılabildiği bilinmektedir. Ayrıca, yapılan çalışmalarda yaşam biçimi ile sağlık durumu, sağlık bakım kullanımı ve sağlık bakım sistemleri arasında ilişki olduğu gösterilmiştir ${ }^{1-4}$.

Sağlık çalışanları, mesleki sorumlulukları ve sosyal rolleri gereği sürdükleri yaşam biçimleri ile rol modeli olma ve sağllk eğitimi yönünden hizmet verdikleri grubu etkileme özelliğine sahiptir. Yapılan çalışmalarda, hekimlerin verdikleri tavsiyelere kendilerinin uymaması durumunda, hastalarina güvenilir ve etkin tıbbi tavsiyeler vermelerinin daha zor olduğu gösterilmiştir ${ }^{5,6}$.

Sağlığ1 geliştirici davranışlar ailede başlamakta ve üniversite eğitimi sırasında şekillenmeye devam etmektedir. Fiziksel, psikolojik, sosyal ve cinsel gelişimlerin devam ettiği ve yeni sorumlulukların gerçekleştiği üniversite yıllarında öğrenciler, yaşam tarzlar1 üzerinde adölesanlara kiyasla daha fazla otonomi ve kontrol sahibi olmaktadırlar. Bu geçiş dönemi, aynı zamanda sağlıklı yaşam biçimi davranışlarının pekiştirildiği bir dönemdir. $\mathrm{Bu}$ nedenle, sağlı̆̆ın korunması ve geliştirilmesinde gençlik dönemindeki gruplara yönelik girişimler önem taşımaktadır ${ }^{7,8}$.

Tablo 1. Türkiye’de üniversite öğrencileriyle SYBD ölçeği kullanılarak yapılan çalışmalar

\begin{tabular}{|c|c|c|c|}
\hline $\begin{array}{l}\text { Çalışmayı yapan araştırıcılar } \\
\text { (yıl) }\end{array}$ & Üniversite & $\begin{array}{l}\text { Çalışmanın yapıldı̆̆ı } \\
\text { fakülte/bölüm }\end{array}$ & siniflar \\
\hline Can ve ark. ${ }^{8}(2008)^{*}$ & İstanbul & Hemşirelik/Sosyal Bilimler & $1-2-3-4$ \\
\hline Zaybak ve Fadıloğlu ${ }^{9}(2000-2001)$ & Ege & $\begin{array}{l}\text { Hemşirelik, } \\
\text { Tip Fakültesi } \\
\text { Bilgisayar Mühendisliği } \\
\text { Istatistik Bölümü }\end{array}$ & $\begin{array}{l}1-3 \\
1-5 \\
1-3 \\
1-3\end{array}$ \\
\hline Ayaz ve ark. ${ }^{10}(2002)$ & Gazi & Hemşirelik & $1-2-3-4$ \\
\hline Çelik ve ark. ${ }^{11}(2008)$ & Onsekiz Mart & Sağlık Yüksek Okulu & $1-2$ \\
\hline Ünalan ve ark. ${ }^{12}(2007)$ & Erciyes & $\begin{array}{l}\text { Sağlık ve Sosyal Meslek Yüksek } \\
\text { Okulu }\end{array}$ & $\begin{array}{l}\text { Basit rastgele } \\
\text { örnekleme } \\
\text { yöntemi }\end{array}$ \\
\hline Yuldırım $^{13}(2004-2005)$ & Cumhuriyet & $\begin{array}{l}\text { Fen Bilimleri Sosyal Bilimler } \\
\text { Sağlık Bilimleri, Meslek Yüksek } \\
\text { Okulları }\end{array}$ & $\begin{array}{l}1-2-3-4- \\
5 \text { ve üzeri }\end{array}$ \\
\hline Cihangiroğlu ve Deveci ${ }^{14}$ (2011) & Firat & Sağlık Yüksekokulu & $1-2-3-4$ \\
\hline Tuğut ve Bekar ${ }^{15}(2004-2005)$ & Cumhuriyet & Tümü & $\begin{array}{l}\text { Tabakalı küme } \\
\text { örneklem }\end{array}$ \\
\hline Ay ve ark. ${ }^{16}$ (2011) & Celal Bayar & $\begin{array}{l}\text { Beden Eğitimi } \\
\text { Sağllk Yüksekokulu } \\
\text { Uygulamalı Bilimler Okulu }\end{array}$ & $1-2-3-4$ \\
\hline Şimşek ${ }^{17}(2011-2012)^{*}$ & 9 Eylül & Tip Fakültesi & 1.sinif \\
\hline Nacar ve ark. ${ }^{18}(2011)^{*}$ & $\begin{array}{l}\text { Yedi farklı üniversite } \\
\text { (Erciyes, Gazi, Konya, } \\
\text { Eskişehir, Ege, Maraş, } \\
\text { Malatya) }\end{array}$ & Tip Fakültesi & 1 ve 6. Sinif \\
\hline Peker ve Bermek ${ }^{19}(2009)^{*}$ & İstanbul & Diş Hekimliği Fakültesi & 1.sinif \\
\hline Hacıhasanoğlu ve ark. ${ }^{20}(2008)$ & Erzincan & $\begin{array}{l}\text { Tüm üniversite öğrencilerinden } \\
\text { random }\end{array}$ & $1-2-3-4$ \\
\hline Karadeniz ve ark. ${ }^{21}(2006)$ & Celal Bayar & Ë̆itim Fakültesi & $1-4$ \\
\hline Altun $22(2004-2005)$ & Kocaeli & İnşaat Mühendisliği & 2 \\
\hline Çoban ve ark. ${ }^{23}$ (2007-2008) & Celal Bayar & $\begin{array}{l}\text { Beden Eğitimi ve Spor } \\
\text { Sağlık Bilimleri } \\
\text { Uygulamalı Bilimler }\end{array}$ & $1-2-3-4$ \\
\hline
\end{tabular}

*İ̧saretli çalışmalarda 52 maddelik SYBD-II ölçeği, diğerlerinde 48 maddelik SYBD-I ölçeği kullanılmıştır. 
Sağlığın geliştirilmesinde, sağlık bilimlerinde eğitim gören öğrenciler hem gençlik döneminde olmaları hem de geleceğin sağlık çalışanı adayı olmaları nedeniyle özel bir konuma ve öneme sahiptirler. Akranlarına ve gelecek dönemlerde topluma rolmodel olmaları bakımından bu gruptaki öğrencilere şu anda ve gelecekte bazı sorumluluklar düşmektedir. Bu durum, sağlık bilimlerinde eğitim gören öğrencilerin sağlıklı yaşam davranışlarının ve bunları etkileyen etmenlerin belirlenmesinin ve bunların yol göstericiliğinde planlamalar yapılmasının gerekliliğini ortaya koymaktadır. Bu konuda yapılmış çalışmalar incelendiğinde; çoğunlukla hemşirelik, çok az sayıda tıp ve diş hekimliği bölümlerinde eğitim gören öğrencilerle ilgili çalışmalara rastlanmıştır ${ }^{8-23}$ (Tablo 1). Ancak sağlik bilimlerinde eğitim gören öğrencilerin karşılaştırıldığı herhangi bir çalışmaya rastlanmamıştır.

$\mathrm{Bu}$ çalışmada, üniversitemizde sağlık bilimlerinin bütün alanlarında (hemşirelik, ebelik, tıp ve diş hekimliği) eğitim gören öğrencilerin sağlıklı yaşam davranışlarının değerlendirilmesi ve karşılaştırılması amaçlanmıştır.

\section{GEREÇ VE YÖNTEM}

Kesitsel tipteki araştırmanın evrenini, 2008-2009 öğretim yılında üniversitemiz Tip Fakültesi'nde (874), Sağlık Yüksek Okulu Ebelik ve Hemşirelik bölümlerinde (547) ve Diş Hekimliği Fakültesi’nde (188) okuyan toplam 1609 öğrenci oluşturdu.

Sağlıklı yaşam davranışları sıklığı \% 50 alındığında, sağlik bilimlerinde okuyan öğrencileri \%95 güvenirlik ile temsil eden en az örneklem büyüklüğü 311 öğrenci olarak hesaplandi. Küme örneklem yapıldığı için bulunan en az örneklem büyüklüğü iki katsayısı ile çarpılarak 622 öğrencinin çalışmaya alınması gerektiği belirlendi.

Fakülte ve bölümlerin ilk ve son sınıfları çalışmaya alındı. Tip Fakültesinin ve Diş Hekimliği Fakültesinin öğrenim süreleri, diğer bölümlerden daha uzun olduğu için, grupların benzer olması amacıyla bu fakültelerin 4. sınıfları da çalışmaya dahil edildi ( $\mathrm{n}=928)$. Veri toplanan günlerde okulda, derste veya stajda bulunan 807 öğrenciye ulaşıldı. Ancak üç öğrencinin çalışmaya katılmayı kabul etmemesi, üç öğrencinin ise veri formunu eksik doldurması nedeniyle araştırma örneklemi 801 öğrenciden (\%86,3) oluştu (Tablo 2).

Bölümlerin idari amirleri ile yüz yüze görüşülüp, yapılması planlanan araştırma hakkında bilgi verilerek önce sözel onayları ardından resmi yazı ile yazılı onayları alındı. Tıp Fakültesi Etik Kurul'undan araştırmayla ilgili etik izin ve çalışmanın başında ögrencilerden yazılı onam alındı.

\section{Veri Toplama Araçları}

Verilerin toplanmasında öğrencilerin sosyodemografik özelliklerini (yaş, cinsiyet, anne eğitim, baba eğitim, aile geliri, aileyle kalma durumu, kendisinde ve ailesinde kronik hastalık varlığ1) sorgulayan bir anket ile Health Promotion Lifestyles Profiles II (HPLP-II) Sağlıklı Yaşam Biçimi Davranışları-II (SYBD-II) ölçeği kullanıldı. Tıp fakültesinde örnekleme alınan sınıflar dışında kalan 10 ögrenci ile pilot bir çalışma yapılarak veri toplama araçlarına son şekli verildi.

Tablo 2. Bölümlere göre öğrencilerin araştırma örneklemine girme oranları

\begin{tabular}{|c|c|c|c|c|c|}
\hline Fakülte-Bölüm & Sinif & $\begin{array}{l}\text { Mevcut } \\
\text { öğrenci } \\
\text { sayısı }\end{array}$ & $\begin{array}{c}\text { Araştırmaya } \\
\text { katılan öğrenci } \\
\text { sayısı }\end{array}$ & $\begin{array}{l}\text { Katılanların } \\
\text { sınıf içindeki } \\
\text { yüzdesi (\%) }\end{array}$ & $\begin{array}{c}\text { Katılan toplam } \\
\text { içindeki } \\
\text { yüzdesi }(\%)\end{array}$ \\
\hline \multirow[t]{3}{*}{ Tip } & 1. sinif & 233 & 187 & 80.3 & 23.3 \\
\hline & 4. sinif & 159 & 121 & 76.1 & 15.1 \\
\hline & 6. sinif & 108 & 97 & 89.8 & 12.1 \\
\hline \multirow[t]{3}{*}{ Diş Hekimliği } & 1. sinif & 43 & 35 & 81.4 & 4.4 \\
\hline & 4. sinif & 45 & 37 & 82.2 & 4.6 \\
\hline & 5. sinif & 28 & 24 & 85.7 & 3.0 \\
\hline \multirow[t]{2}{*}{ Hemşirelik } & 1. sinif & 99 & 91 & 91.9 & 11.4 \\
\hline & 4. sinif & 60 & 59 & 98.3 & 7.4 \\
\hline \multirow[t]{2}{*}{ Ebelik } & 1. sinif & 98 & 98 & 100 & 12.2 \\
\hline & 4. sinif & 55 & 52 & 94.6 & 6.5 \\
\hline Toplam & 1., 4., 5., 6. sinif & 928 & 801 & 86.3 & 100 \\
\hline
\end{tabular}




\section{Sağlıklı Yaşam Biçimi Davranışları Ölçeği}

SYBD ölçeği, Pender'in "Sağlı̆̆1 Geliştirme Modeli"ne dayandırılarak 1987 yılında Walker ve ark. tarafından geliştirilmiş olup, bireyin sağlıklı yaşam biçimi ile ilişkili olarak sağlığı geliştiren davranışları ölçen bir ölçektir. Ölçek, 1996 yılında tekrar çalışılarak revize edilmiş ve SYBD-II ölçeği olarak adlandırılmıştır ${ }^{24}$. Ölçeğin ülkemizdeki geçerlik ve güvenirlik çalışması Bahar ve ark. tarafindan yapılmıştır ${ }^{25}$.

SYBD-II ölçeği, 4 dereceli olup ölçeğin bütün maddeleri olumludur. Her bir madde için sırasıyla 1 (hiçbir zaman), 2 (bazen), 3 (sı1k sık) ve 4 (düzenli olarak) puan verilir. Ölçekte toplam 52 ifade yer almaktadır. En düşük puan 52, en yüksek puan 208 'dir. Ölçekten alınan puanların yükselmesi bireyin belirtilen sağlık davranışlarını yüksek düzeyde uyguladığını gösterir. Uygulama süresi yaklaşık 10-12 dakika olan ölçeğin 6 alt başlığı bulunmaktadır: Tinsellik; bireyin yaşam amaçlarını, bireysel olarak kendini geliştirme yeteneğini ve kendini ne derecede tanıdığını ve memnun edebildiğini belirler (Tinsellik alt ölçeği madde numaraları: 6, 12, 18, 24, 30, 36, 42, 48, 52). Beslenme; bireyin öğünlerini seçme ve düzenleme, yiyecek seçimindeki değerlerini belirler (Beslenme alt ölçeği madde numaraları: 2, 8, 14, 20, 26, 32, 38, 44, 50). Fiziksel aktivite; sağlıklı yaşamın değişmez bir öğesi olan egzersiz uygulamalarının birey tarafindan ne düzeyde uygulandığını gösterir (Fiziksel aktivite alt ölçeği madde numaraları: 4, 10, 16, 22, 28, 34, 40, 46). Sağlık sorumluluğu; bireyin kendi sağllğ1 üzerindeki sorumluluk düzeyini, sağllğına ne düzeyde katıldığını belirler (Sağlık sorumluluğu alt ölçeği madde numaraları: 3, 9, 15, 21, 27, 33, 39, 45, 51). Kişiler arası ilişki; bireyin yakın çevresi ile iletişimini ve süreklilik düzeyini belirler (Kişiler arası ilişki alt ölçeği madde numaraları: 1, 7, 13, 19, 25, 31, $37,43,49)$. Stres yönetimi; bireyin stres kaynaklarını tanıma düzeyini ve stres kontrol mekanizmalarını belirler (Stres yönetimi alt ölçeği madde numaralar1: 5, 11, 17, 23, 29, 35, 41, 47).

\section{İstatistiksel analiz}

Bilgisayar ortamına aktarılan veriler istatistik paket programlar kullanılarak analiz edildi. Öğrencilerin tanıtıcı özellikleri ile ilgili veriler; sayı, yüzde ve ortalama ile değerlendirildi. Bağımsız değişkenlerle SYBD ölçeği ve alt gruplarının puan ortalamaları arasındaki farklılığın analizi için student-t testi ve varyans analizleri (ANOVA ve Kruskal Wallis), gruplar arasındaki farklılı̆̆ın kaynağını saptamak için ise Bonferoni yöntemi kullanıldı. P değerinin 0,05'ten küçük olması istatistiksel olarak anlamlı kabul edildi.

\section{BULGULAR}

Araştırmaya katılan öğrencilerin yaş ortalaması 21.5 \pm 2.21 (17-34) olarak bulundu. Öğrencilerin; \% 53’ü $\leq 21$ yaş grubundaydı ve \% 60’1 kadındı. Tip fakültesinde okuyan ögrenci sayısının fazla olması nedeniyle araştırmaya alınan öğrencilerin yarısını tıp fakültesi öğrencileri oluşturdu. Öğrencilerin yaş, cinsiyet ve sınıf özelliklerinin öğrenim gördükleri bölümlere göre dağılımı Tablo 3'de verilmiştir..

Tablo 3. Öğrencilerin yaş, cinsiyet ve sınıf özelliklerinin öğrenim gördükleri bölümlere göre dağılımı.

\begin{tabular}{|c|c|c|c|c|c|c|}
\hline & & Tip & $\begin{array}{l}\text { Diş } \\
\text { Hekimliği }\end{array}$ & Hemşirelik & Ebelik & Toplam \\
\hline & & $\mathrm{n}(\%)$ & $\mathrm{n}(\%)$ & $\mathrm{n}(\%)$ & $\mathrm{n}(\%)$ & $\mathrm{n}(\%)$ \\
\hline \multirow[t]{3}{*}{ Yaş grubu } & $17-21$ & $202(47.7)$ & $34(8.0)$ & $90(21.2)$ & $98(23.1)$ & $424(100)$ \\
\hline & $22-35$ & $203(54.0)$ & $62(16.4)$ & $60(16.0)$ & $51(13.6)$ & $376(100)$ \\
\hline & Toplam & $405(50.6)$ & $96(12.0)$ & $150(18.8)$ & 149(18.6) & $800(100)$ \\
\hline \multirow[t]{3}{*}{ Cinsiyet } & Erkek & $232(72.5)$ & $54(16.9)$ & $34(10.6)$ & $0(0)$ & $320(100)$ \\
\hline & Kadin & $174(36.2)$ & $42(8.7)$ & $116(24.1)$ & $149(31.0)$ & $481(100)$ \\
\hline & Toplam & $406(50.7)$ & $96(12.0)$ & $150(18.7)$ & $149(18.6)$ & $801(100)$ \\
\hline \multirow[t]{5}{*}{ Sinif } & 1. sinif & $187(45.6)$ & $35(8.5)$ & $91(22.1)$ & $98(23.8)$ & $411(100)$ \\
\hline & 4. sinif & $121(45.0)$ & $37(13.8)$ & $59(21.9)$ & $52(19.3)$ & $269(100)$ \\
\hline & 5. sinif & $0(0)$ & $24(100)$ & $0(0)$ & $0(0)$ & $24(100)$ \\
\hline & 6. sinif & $97(100)$ & $0(0)$ & $0(0)$ & $0(0)$ & $97(100)$ \\
\hline & Toplam & $405(50.6)$ & $96(12.0)$ & $150(18.7)$ & $150(18.7)$ & $801(100)$ \\
\hline
\end{tabular}


Eğitim düzeyi açısından, öğrencilerin annelerinin $\% 21.3$ 'ü okula gitmemiş, \%41.4'ü ilköğretim, \%22.4'ü lise, \%14.8’i üniversite ve üzeri grubundayd1. Babalarda bu oranlar ,okula gitmemiş $\% 4,6$, ilköğretim $\% 36.5$, lise $\% 28.1$, üniversite ve üzeri \%30.8 şeklindeydi. Öğrencilerin \% 46.5’ i ailesi ile birlikte kalıyordu ve $\% 60.3$ 'ü aile gelirinin orta düzeyde olduğunu bildirdi. Öğrencilerin \% 9.1' inin hekim tarafindan tanısı konulmuş bir hastalığ1 olduğu (ilk üç sırada gastrointestinal (\%2.24), alerjikimmünolojik (\%1.49) ve psikiyatrik hastaliklar (\%1.12)), \% 53.4' ünün ailesinde ilaç kullanımı gerektiren kronik bir hastalık bulunduğu (ilk üç sirada hipertansiyon (\% 22.34), diyabet (\% 14.48) ve kalp-damar hastalıkları (\% 12.10) saptand1.
Öğrencilerin, SYBD ölçeği toplam puan ortalamas1 124.30 17.92 , alınan en düşük puan 77 , en yüksek puan 183' tü. Alt ölçeklerden alınan ortalama puanlar, en yüksekten en düşüğe doğru sıralandığında; sıralamanın tinsellik, kişilerarası ilişki, sağlık sorumluluğu, beslenme, stres yönetimi ve fizik aktivite şeklinde olduğu görüldü (Tablo 4).

Tablo 5'te görüldüğü gibi 22 yaş ve üstü grubundaki öğrencilerin fiziksel aktivite ve stres yönetimi alt ölçekleri dışındaki tüm puanları 21 yaş ve altı grubuna göre daha yüksek olduğu saptanmış, ancak SYBD ölçeği ve tüm alt ölçeklerin puan ortalamalarında gruplar arasında istatistiksel olarak anlamlı fark bulunmamıştır ( $\mathrm{p}>0.05$ ).

Tablo 4. Ölçeklerden alınan ortalama puanlar, alt ve üst puan değerleri ve madde puan ortalamaları

\begin{tabular}{|l|c|c|c|}
\hline & Ortalama \pm SS & $\begin{array}{c}\text { Alt ve üst puan } \\
\text { değerleri }\end{array}$ & $\begin{array}{c}\text { Madde puan } \\
\text { ortalamaları } \pm \text { SS }\end{array}$ \\
\hline Sağlık sorumluluğu & $19.98 \pm 4.19$ & $9-36$ & $2.22 \pm 0.47$ \\
\hline Fiziksel aktivite & $15.94 \pm 4.38$ & $8-32$ & $1.99 \pm 0.55$ \\
\hline Beslenme & $19.45 \pm 3.76$ & $9-34$ & $2.16 \pm 0.42$ \\
\hline Tinsellik & $25.70 \pm 4.20$ & $11-36$ & $2.86 \pm 0.47$ \\
\hline Kişiler arası ilişki & $24.96 \pm 3.93$ & $13-36$ & $2.77 \pm 0.44$ \\
\hline Stres yönetimi & $18.61 \pm 3.44$ & $9-30$ & $2.33 \pm 0.43$ \\
\hline SYBD toplam & $124.30 \pm 17.92$ & $77-183$ & $2.39 \pm 0.35$ \\
\hline
\end{tabular}

Tablo 5. Öğrencilerin yaş, cinsiyet, sınıf, bölüm gruplarına göre ölçek puanları

\begin{tabular}{|c|c|c|c|c|c|c|c|c|}
\hline & & $\begin{array}{l}\text { Sağlık } \\
\text { sorumluluk } \\
\text { Ortalama } \pm \text { S } \\
\text { S } \\
\end{array}$ & $\begin{array}{l}\text { Fiziksel } \\
\text { aktivite } \\
\text { Ortalama } \pm S \\
\text { S } \\
\end{array}$ & $\begin{array}{l}\text { Beslenme } \\
\text { Ortalama } \pm \text { S } \\
\text { S }\end{array}$ & $\begin{array}{l}\text { Tinsellik } \\
\text { Ortalama } \pm \text { S } \\
\text { S }\end{array}$ & $\begin{array}{l}\text { Kişiler } \\
\text { arası ilişki } \\
\text { Ortalama } \pm \text { S } \\
\text { S } \\
\end{array}$ & $\begin{array}{l}\text { Stres } \\
\text { yönetimi } \\
\text { Ortalama } \pm S \\
\text { S } \\
\end{array}$ & $\begin{array}{l}\text { Toplam } \\
\text { Ortalama } \pm \text { S } \\
\text { S }\end{array}$ \\
\hline Yaş & $\begin{array}{l}22 \text { yaş } \\
\text { üstüi }\end{array}$ & $20.29 \pm 4.08$ & $15.72 \pm 4.53$ & $19.54 \pm 3.72$ & $25.74 \pm 4.13$ & $25.02 \pm 3.81$ & $18.40 \pm 3.45$ & $124.76 \pm 17.4$ \\
\hline \multirow{3}{*}{ Cinsiye } & Erkek & $18.90 \pm 4.11$ & $16.93 \pm 4.98$ & $18.80 \pm 3.88$ & $25.31 \pm 4.52$ & $24.52 \pm 4.22$ & $18.25 \pm 3.56$ & $123.27 \pm 19.9$ \\
\hline & Kadın & $20.69 \pm 4.09$ & $15.27 \pm 3.79$ & $19.86 \pm 3.62$ & $25.96 \pm 3.96$ & $25.28 \pm 3.68$ & $18.84 \pm 3.35$ & $125.00 \pm 16.3$ \\
\hline & $\mathrm{p}^{*}$ & 0.000 & 0.000 & 0.000 & 0.045 & 0.015 & 0.018 & 0.273 \\
\hline \multirow[t]{3}{*}{ Sinif } & 1 & $19.68 \pm 4.33$ & $16.17 \pm 4.47$ & $19.35 \pm 3.83$ & $25.64 \pm 4.28$ & $24.98 \pm 4.14$ & $18.79 \pm 3.54$ & $124.06 \pm 18.9$ \\
\hline & 4 & $20.58 \pm 4.12$ & $15.83 \pm 4.22$ & $19.73 \pm 3.46$ & $25.79 \pm 3.99$ & $24.85 \pm 3.76$ & $18.60 \pm 3.30$ & $125.30 \pm 16.6$ \\
\hline & 5 & $19.79 \pm 3.23$ & $16.54 \pm 4.09$ & $19.38 \pm 3.35$ & $26.25 \pm 4.24$ & $25.32 \pm 3.61$ & $19.00 \pm 3.02$ & $124.95 \pm 12.8$ \\
\hline \multirow{4}{*}{ Bölüm } & $\begin{array}{l}\text { Diş } \\
\text { Hekimliği }\end{array}$ & $20.51 \pm 3.96$ & $17.00 \pm 5.10$ & $20.17 \pm 3.75$ & $26.31 \pm 3.81$ & $25.16 \pm 3.40$ & $19.52 \pm 3.17$ & $126.93 \pm 15.7$ \\
\hline & $\begin{array}{l}\text { Hemşireli } \\
\mathrm{k}\end{array}$ & $21.29 \pm 4.17$ & $16.25 \pm 4.15$ & $20.11 \pm 3.19$ & $26.29 \pm 4.09$ & $25.95 \pm 4.05$ & $19.15 \pm 3.36$ & $129.31 \pm 17.5$ \\
\hline & Ebelik & $21.03 \pm 4.29$ & $15.21 \pm 3.57$ & $19.56 \pm 3.64$ & $26.04 \pm 3.84$ & $25.43 \pm 3.64$ & $18.73 \pm 3.42$ & $124.99 \pm 16.6$ \\
\hline & $\begin{array}{l}\mathrm{p}^{\ddagger} \\
\text { Fark } \\
\text { kaynağ1 }\end{array}$ & $\begin{array}{l}0.000 \\
\text { Tip } \\
\text { Fakültesi- } \\
\text { Tüm gruplar }\end{array}$ & $\begin{array}{l}0.014 \\
\text { Diş } \\
\text { Hekimliği- } \\
\text { Ebelik }\end{array}$ & $\begin{array}{l}0.002 \\
\text { Tip- Diş } \\
\text { Hekimliği } \\
\text { Tipi- } \\
\text { Hemşirelik } \\
\end{array}$ & $\begin{array}{l}0.009 \\
\text { Tip } \\
\text { Fakültesi- } \\
\text { Hemşirelik }\end{array}$ & $\begin{array}{l}0.001 \\
\text { Tip } \\
\text { Fakültesi- } \\
\text { Hemşirelik }\end{array}$ & $\begin{array}{l}0.000 \\
\text { Tip- Diş } \\
\text { Hekimliği } \\
\text { Tip- } \\
\text { Hemşirelik }\end{array}$ & $\begin{array}{l}0.000 \\
\text { Tip - Diş } \\
\text { Hekimliği } \\
\text { Tip - } \\
\text { Hemşirelik }\end{array}$ \\
\hline
\end{tabular}

${ }^{*}$ t test, ${ }^{\dagger}$ Kruskal-Wallis, ${ }^{\star A N O V A}$ 
Öğrencilerin cinsiyetine göre SYBD ve alt ölçeklerinin puan ortalamaları incelendiğinde, erkek öğrencilerin fiziksel aktivite alt ölçeğindeki puan ortalamasının yüksek, diğer alt ölçeklerdeki puan ortalamalarının düşük olduğu görülmüştür. Tüm alt ölçeklerde puan ortalamalarında gruplar arasındaki farklar istatistiksel olarak anlamlı bulunmuştur $(p<0.05)$. SYBD ölçeği toplam puan ortalamasında kadın cinsiyet daha yüksek puan almış ancak bu fark istatistiksel olarak anlamlı bulunmamıştır $(\mathrm{p}>0.05)$ (Tablo 5).

Öğrencilerin bulundukları sınıflara göre ölçek puan ortalamaları incelendiğinde, sağlık sorumluluğu alt ölçeğinde gruplar arasında istatistiksel olarak anlamlı fark saptanmıştır $(p<0,05)$. Bu farkın, 1. sınıf ve 4 . sınıf grupları arasındaki farktan kaynaklandığı bulunmuştur. Öğrencilerin bulundukları sınıflara göre diğer alt ölçekler arasında istatistiksel olarak anlamlı fark bulunmamıştır ( $\mathrm{p}>0.05)$ (Tablo 5). Öğrencilerin öğrenim gördükleri bölümlere göre
SYBD ve alt ölçeklerinin puan ortalamaları incelendiğinde, bölümlere göre SYBD ölçeği ve tüm alt ölçeklerin puan ortalamalarında gruplar arasında istatistiksel olarak anlamlı fark bulunmuştur $(\mathrm{p}<0.05)$. Fark kaynakları incelendiğinde, fiziksel aktivite alt ölçeğinde bu farkın diş hekimliği ve ebelik öğrencilerinin arasındaki farklılıktan, diğerlerinde tıp fakültesinden kaynaklandığ̆ saptanmıştır. Tıp fakültesi öğrencilerinin fiziksel aktivite alt ölçeği dışındaki tüm alt ölçeklerde ve ölçek toplamında en düşük puan ortalamalarını aldığı dikkati çekmiştir (Tablo 5).

Anne eğitim düzeyine göre sadece sağlık sorumluluğu; baba eğitim düzeyine göre ise sağllk sorumluluğu ve stres yönetimi alt ölçeklerinde gruplar arasındaki fark istatistiksel olarak anlamlı bulunmuştur. Aile gelir düzeyi yüksek olan öğrencilerin, sağllk sorumluluğu puan ortalamalarının anlamlı olarak daha düşük olduğu saptanmıştır (Tablo 6).

Tablo 6. Öğrencilerin ebeveynlerinin eğitim ve aile gelir durumlarına göre ölçek puanları

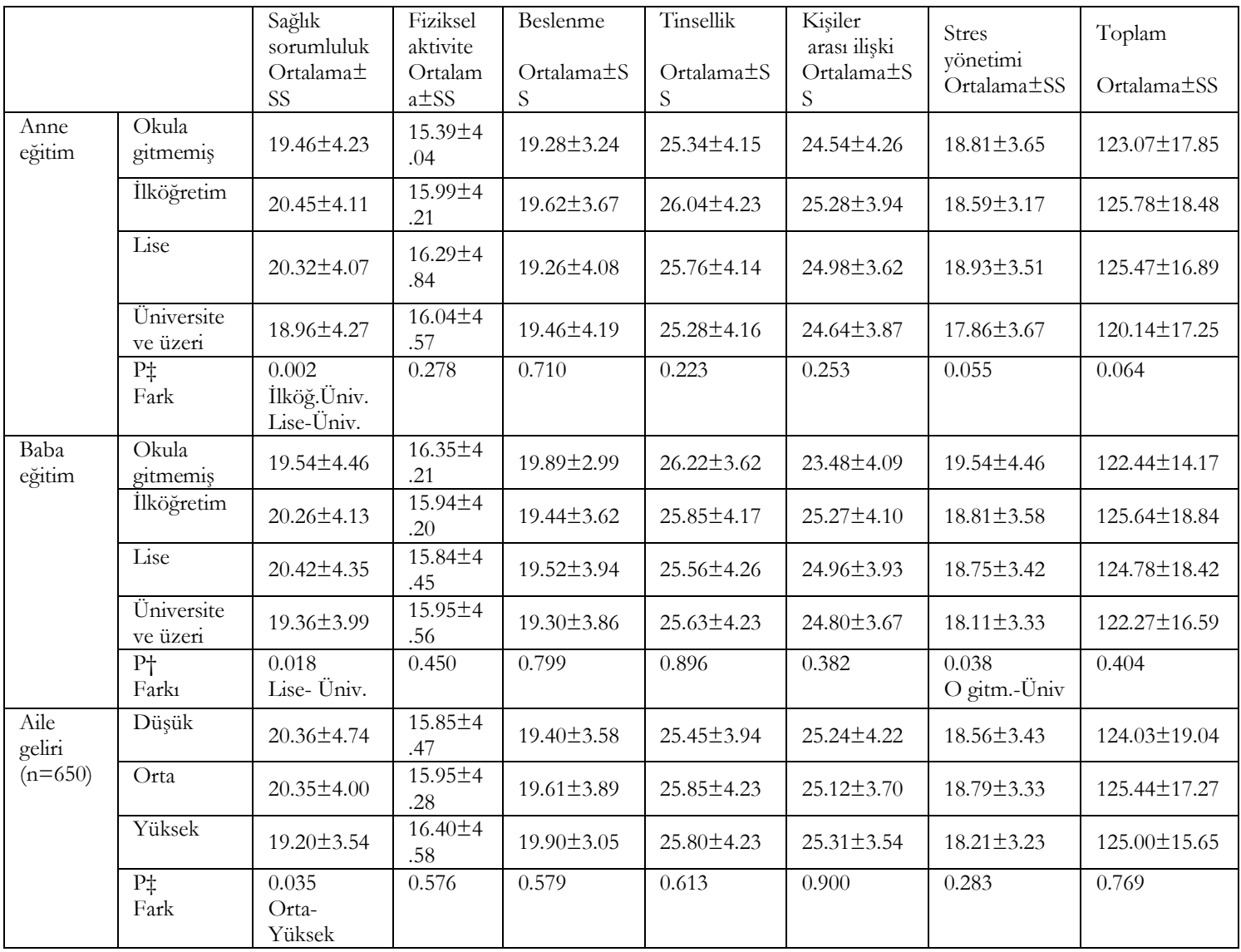

†Kruskal-Wallis, $\ddagger$ ANOVA 
Ailesi ile birlikte yaşayan öğrenciler SYBD ölçeği ve tüm alt ölçeklerden, ailesi ile birlikte yașamayanlara göre daha fazla puan almışlardır. Ancak sadece sağlık sorumluluğu alt ölçeğinde gruplar arasındaki fark istatistiksel olarak anlamlı bulunmuştur $(\mathrm{p}=0.014)$.

Öğrencilerin kendilerinde ve ailelerinde mevcut olan kronik hastalıklar ile SYBD ölçeği puan ortalamaları arasında istatistiksel olarak anlamlı bir ilişki bulunmamıştır ( $\mathrm{p}>0.05)$.

\section{TARTIŞMA}

Sağlık Bilimleri bölümlerinde (Tip Fakültesi, Diș Hekimliği, Hemşirelik ve Ebelik) okuyan öğrencilerin sağlıklı yaşam davranışlarının, SYBD-II ölçeği kullanılarak değerlendirildiği bu çalışmada, ögrencilerin SYBD puanları ortalamasinin orta düzeyde olduğu ve bu bulgunun yurt içi ve yurt dış1 üniversite öğrencileri ile yapilan çalışmalarla uyumlu olduğu saptanmıştır.

Öğrencilerin, alt ölçeklere verdikleri yanıtlar değerlendirildiğinde, siralama, en yüksekten en düşüğe doğru; tinsellik, kişiler arası ilişki, sağlık sorumluluğu, beslenme, stres yönetimi ve fizik aktivite alt ölçeği şeklindedir. Benzer olarak, üniversite öğrencileri ile yapılan birçok çalışmada, ilk sırayı tinselliğin, son sırayı fiziksel aktivitenin aldığ1 görülmüştür ${ }^{8,12,13,18,} \quad{ }^{22}$. Ancak farklı sıralamaların saptandığı çalışmalar da bulunmaktadır. Örneğin; Şimşek ve arkadaşlarının İzmir'de Tip Fakültesi 1. Sinıf öğrencileriyle yaptıkları çalışmada kişilerarası ilişkiler başta yer almaktadır ve ardından tinsellik, beslenme, sağlık sorumluluğu, stres yönetimi ve fiziksel aktivite gelmektedir ${ }^{17}$. Peker ve Bermek'in İstanbul'da Diş Hekimliği öğrencileri ile yaptıkları çalışmada ilk sırayı tinsellik alırken son sırayı sağlık sorumluluğu almıştır ${ }^{19}$. Birleşik Devletler'de hemşirelik öğrencileri ile yapılmış bir çalışmada sıralama; kişiler arası ilişki, tinsellik, beslenme, fiziksel aktivite, stres yönetimi ve sağllk sorumluluğu şeklindedir ${ }^{27}$. Japonya'da üniversite ögrencilerinde yapılan çalışmada ise sıralama kişilerarası ilişki, stres yönetimi, tinsellik, beslenme, fiziksel aktivite ve sağlık sorumluluğu şeklindedir ${ }^{28}$. $\mathrm{Bu}$ farklılıkların nedenlerinin kültürel yap1, inanç sistemi, bireysel ve çevresel özellikler gibi faktörler olabilir. "Sağllğ̆ Geliştirme Modeli"ne göre, bireylerin yaşları arttıkça sağlık davranışları kazanımları artmaktadır. Genel olarak literatür bilgisi de bu yöndedir' ${ }^{9,12,13,21,27}$. Çalıșmamızda da bununla uyumlu olarak 22 yaș ve üstü öğrencilerin fiziksel aktivite ve stres yönetimi alt ölçekleri dışındaki tüm puanları 21 yaş ve altı grubuna göre daha yüksek olduğu görülmüş, ancak SYBD ölçeği ve tüm alt ölçeklerin puan ortalamalarında gruplar arasında istatistiksel olarak anlamlı farklılık bulunmamıştır. Çalışmamızda 22 yaş ve üstü grubun çoğunluğunu tıp öğrencilerinin oluşturması ve yaş arttıkça tıp ögrrencilerinin stres ve sorumluluklarının artması bu bulguyu etkilemiş olabilir. Nitekim Nacar ve arkadaşlarının yedi ayrı tıp fakültesinde yaptıkları çalışmada, büyük yaş grubunun puanlarının küçük yaş grubuna göre daha düşük olduğu saptanmıştır ${ }^{18}$.

Çalışmamızda erkek ve kadın öğrenci grupları arasındaki farklar incelendiğinde, fizik aktivite ölçeğinde erkek öğrenciler daha yüksek puan almış ve bu fark istatistiksel olarak anlamlı bulunmuştur. Yurt içi ve yurt dıșı çalışmalar incelendiğinde, bir kısminda istatistiksel olarak anlamlllik bulunmasa da çalışmamızla uyumlu olarak, erkek öğrencilerin fiziksel aktivite düzeyleri kız öğrencilerden daha yüksek bulunmuștur. Erkek öğrencilerin fiziksel aktivite puanının kızlara göre anlamlı olarak daha yüksek olmasının nedenleri; bu tür aktivitelerin genellikle ders programlarından sonra akşam saatlerinde yapılabilmesi nedeniyle kız öğrencilerin akşam saatlerinde dişarıya çıkma konusunda kısıtlılıklar yaşaması, erkeklerin akșam saatlerinde yapabilecekleri egzersiz imkanlarının daha çok olması (ülkemiz için halı sahada futbol maçları gibi), erkeklerin egzersizi (özellikle grup sporlarını) aynı zamanda sosyalleşmek ve stres atmak için tercih ediyor olmaları olabilir. Bundan sonra yapilacak araştırmalarda, kız öğrencilerin egzersiz yapmalarının önündeki engellerin ortaya çıkarılması ve bu bulguların yol göstericiliğinde girişimlerde bulunulması gerektiği düşünülmüştür.

Kız öğrenci grubu fiziksel aktivite dışındaki tüm alt ölçeklerde, erkek öğrenci grubuna göre daha yüksek puan almış ve bu farklar SYBD toplam puanı dişında istatistiksel olarak anlamlı bulunmuştur. Yapılan çalışmaların bir kısmında sağlık davranışları açısından cinsiyetler arası farklilık saptansa da saptanmayan çalışmalar da bulunmaktadır ${ }^{9,13,18,21,26,30}$. Farklı kültürlerde, farklı cinsiyetlerden beklenen rol ve sorumluluklar sağlık algısını ve dolayısıyla sağlıklı yaşam davranışlarını etkiliyor olabilir. Çalışmamızda sınıflara göre ölçek puan ortalamaları incelendiğinde, sadece sağlık sorumluluğu ölçeğinde 4. sinıf öğrencileri, 1. sınıf öğrencilerine göre sınırda anlamlı 
olarak $(\mathrm{p}=0.05)$ daha yüksek puan almışlardır. Ayaz ve arkadaşlarının Ankara'da hemşirelik öğrencileri ile yaptıkları çalışmada da çalışmamızla benzer doğrultuda üst sınıfların sağlık sorumluluğu puan ortalaması anlamlı olarak daha yüksek bulunmuştur ${ }^{10}$. Aslinda ilerleyen sinıflarda ögrencilerin uyum düzeylerinin ve aldıkları eğitim sonrası, sağlıklı yaşam konusundaki bilgi düzeylerinin artması, bununla birlikte sağlik davranışlarının olumlu yönde değişmeye başlaması beklenir. Ancak, sinıflar arasında anlamlı farklilık saptanmayan çalışmalar olduğu gibi beklenin tam tersi sonuçlar da bildirilmiştir',13,21. Nacar ve arkadaşlarının yaptıkları çalışmada tıp fakültesi 1. sınıf öğrencilerinin sağlık sorumluluğu, tinsellik, fiziksel aktivite, stres yönetimi ve SYBD toplam puanları 6. Sınıf öğrencilerine göre anlamlı olarak daha yüksek bulunmuştur ${ }^{18}$. Sınıf arttıkça diğer sağlık davranışlarında beklenen değişimin olmaması bu konudaki eğitimin eksik olduğunu veya uygulamaya yönelik girişimlere gereksinim olduğunu düșündürmektedir.

Çalışmamızın en dikkat çekici ve en önemli sonuçlarından biri tıp fakültesi öğrencilerinin, fizik aktivite ölçeği dışında tüm alt ölçeklerde ve ölçek toplamında diğer bölümlere göre puan ortalamasının anlamlı olarak daha düşük bulunmuş olmasıdır. Ulaşılabilen araştırmalar arasında, tıp fakültesi öğrencilerinin diğer bölümlerle karşılaştırılmasıyla ilgili ayrıntılı bilgi veren tek çalışma Zaybak ve Fadıloğlu'nun çalışmasıdır'? . Diğer çalışmalarda sağlık bilimleri öğrencileri toplu olarak değerlendirildiği için tıp fakültesi öğrencileri hakkında yorum yapılamamaktadır ${ }^{13,15}$. Zaybak ve Fadıloğlu'nun çalışmalarında, bizim bulgularımızdan farklı olarak tıp fakültesi öğrencilerinin SYBD puanlarının diğer bölümlere (hemşirelik, bilgisayar mühendisliği, istatistik) göre daha yüksek olduğu ancak aradaki farkın anlamlı olmadığı bulunmuștur' ${ }^{9}$. Çalıșmamızda tıp öğrencilerinin daha çok erkeklerden oluşması ve erkeklerin kadın grubuna göre sağlıklı yaşam davranışlarının daha düşük olması bu bulguyu etkilemiş olabilir. Ayrıca diğer okullardan farklı olarak tıp fakültesi grubunun 6.sınıf öğrencileri kapsaması ve bu dönemdeki öğrencilerin stres ve sorumluklarının fazla olması da etkili olmuş olabilir.

Ailesi ile birlikte yaşayan öğrenciler, ailesinden ayrı yaşayanlara göre sağl1k sorumluluğu alt ölçeğinden daha yüksek puan almışlardır ve bu fark istatistiksel olarak anlamlı bulunmuştur. Zaybak ve Fadıloğlu'nun çalışmasında, ailesi ile kalan öğrencilerin beslenme ve kişiler arası ilişki alt ölçeklerinde anlamlı bir şekilde daha yüksek puan aldığ1 saptanmıştır?. Ünalan ve ark. çalışmasında, fizik aktivite, stres yönetimi ve ölçek toplamında ailesi ile birlikte yaşayanların anlamlı düzeyde daha yüksek puan aldığ1 bulunmuştur ${ }^{12}$. Yıldırım'ın çalışmasında ise, sağlık sorumluluğu açısından anlamlı fark olmadığı, ancak evde ailesi ile kalan öğrencilerin egzersiz alt ölçeğinden anlamlı olarak daha yüksek puan aldığı saptanmıştır ${ }^{13}$. Bu durum, evde ailesiyle kalan öğrencilerin, kendilerine ve sağlıklarına daha fazla zaman ayırabildiklerini, aile içi etkileşimin onları olumlu yönde etkilediğini düşündürebilir. Şehir ve yaşam şartlarının değişmemesi, öğrencilerin aile içinde kazandığ alışkanlıklarını devam ettirmesini de sağlıyor olabilir. Ayrıca aile ile birlikte kalmak, öğrencilere daha iyi bir ekonomik durum sağlıyor olabilir.

Beklenenden farklı olarak annesi üniversite mezunu olan öğrencilerin sağlık sorumluluğu, babas1 üniversite mezunu olan öğrencilerin ise sağlık sorumluluğu ve stres yönetimi puan ortalamalarının anlamlı olarak düşük olduğu görülmüştür. Nacar ve arkadaşlarının tıp öğrencileri ile yaptıkları çalışmada ebeveynleri lise ve üzeri okuldan mezun olanların SYBD toplam puanı daha az eğitim almış gruplara göre anlamlı olarak yüksek bulunmuştur ${ }^{18}$. Ankara ve Sivas'ta yapılan çalışmalarda, anne eğitim düzeyi yüksek olan öğrencilerin sağlık sorumluluğu puan ortalamalarının anlamlı olarak daha yüksek olduğu, Manisa'da yapılan çalışmada ise anne eğitiminin sağlik sorumluluğunu etkilemediği saptanmıştır ${ }^{10,13,21}$. Meksika'da yapılan çalışmada anne eğitim düzeyi arttıkça beslenme, fiziksel aktivite, stres yönetimi, kişiler arası ilişki alt ölçeklerinde ve ölçek toplamında puan ortalamalarının anlamlı olarak arttığı görülmüştür ${ }^{26}$.

Manisa'da ve Sivas'ta yapılmış olan çalışmalarda, baba eğitiminin öğrencilerin sağlıklı yaşam biçimi davranışlarını etkilemediği görülmüştür ${ }^{13,21}$. Meksika'daki çalışmada baba eğitim düzeyi arttıkça stres yönetimi, kişiler arası ilişki, tinsellik alt ölçeklerinde ve ölçek toplamında puan ortalamalarının anlamlı olarak arttığı bulunmuştur ${ }^{26}$. Ebeveynlerin eğitim durumları ile ilgili ortaya çıkan bu farklı sonuçların, sağlığı geliştirme modelini etkileyen diğer faktörlerin etkisi nedeniyle oluştuğu ve bu konuda daha kapsamlı araştırmalar yapılması gerektiği düşünülmüştür. Yüksek aile gelir düzeyine sahip olan öğrencilerin sağllk sorumluluğu puan ortalamaları, diğer gruplara göre anlamlı olarak daha 
düşüktür. Literatürde aile gelir düzeyi ile SYBD ve alt ölçekleri arasında pozitif yönde ilişki bulan çalışmalar çoğunluktadır ${ }^{18}$. İzmir'de yapılmış olan çalışmada, aile gelir düzeyi arttıkça sağlik sorumluluğu, beslenme ve tinsellik alt ölçeklerinde anlamlı puan artışları saptanmıştır' ${ }^{9}$. Ankara'daki çalışmada, sosyoekonomik düzeyi yüksek olanların beslenme alt ölçeğinde en yüksek puan ortalamasını aldığı, Manisa ve Meksika'daki çalışmalarda sosyoekonomik düzey yükseldikçe SYBD puan ortalamalarının anlamlı olarak arttığ1 görülmüştür ${ }^{10,21,26}$. Bizim bulgumuzun literatürden farklı olması ögrencilerin aile gelirleri hakkında bilgi sahibi olmamalarından, ve/veya eksik, yanlış bilgiden kaynaklanmış olabilir.

Öğrencilerdeki kronik hastalık varlığına göre SYBD ölçeği ve tüm alt ölçeklerin puan ortalamalarında gruplar arasında istatistiksel olarak anlamlı fark bulunmamıştır. Ancak kronik bir hastalığ1 olan öğrencilerin, ölçeğin tamamından aldıkları toplam puanın, hastalığı olmayan gruba göre, daha yüksek olduğu görülmüştür. Birçok çalışma da kronik hastalık olup olmaması ile sağlıklı yaşam biçimi davranışları arasında anlamlı bir ilişki bulunmamıştır $9,13,18$. Bu durum kronik hastalığ1 olan öğrenci sayısının azlığından, var olan hastalıkların yönetiminde yașam tarzı değișiklikleri olmamasından veya bu konudaki eğitim eksikliğinden kaynaklanabilir. Nitekim, beklendiği gibi Ayaz ve ark.'nın çalışmasında sürekli takip ve tedavi gerektiren hastalığ1 olanlarda, sağlık sorumluluğu puanlarının anlamlı olarak daha yüksek olduğu saptanmiştır ${ }^{10}$.

Öğrencilerin ailelerinde kronik hastalık varlığına göre SYBD ölçeği ve tüm alt ölçeklerin puan ortalamalarında gruplar arasında istatistiksel olarak anlamlı fark bulunmamıştır. Çelik ve ark.'nın çalışmasında da çalışmamızla benzer sonuçlar bulunmuştur ${ }^{11}$. Oysa, ögrencilerin ailesinde var olan hekim tanılı kronik hastalıklarda ilk üç sırayı primer korunmasında sağlıklı yaşam tarzının yer aldığı hipertansiyon, diyabet, kalp-damar hastalıkları gibi ailesel yüklülüğü olan hastalıklar oluşturmaktadır. Bu durum, ailede mevcut olan hastalıklar ve korunma hakkında yeterli bilgi sahibi olunmaması ile ilgili olabilir.

$\mathrm{Bu}$ çalışmada, geleceğin sağlık çalışanları ve aynı zamanda rol modelleri olan sağlik bilimleri öğrencilerinin, sağlıklı yaşam davranışlarının beklenenden farklı olarak akranları gibi orta düzeyde olduğu ve tıp öğrencilerinin puanlarının diğer sağlık bilimleri öğrencilerine göre anlamlı olarak daha düşük olduğu saptanmıştır. Ayrıca sınıf düzeyi arttıkça sağlık davranışlarında beklenen olumlu ve anlamlı değişimin olmaması bu konudaki eğitim gereksinimini ortaya koymuştur. Bulgularımızın bu konuda planlanacak girişimler için yol gösterici olması açısından aşağıda bazı öneriler sunulmuştur:

1. Sağlıklı yaşam davranışları ile ilgili eğitim programları olan bölümlerin çalışmamızda saptanan bulgular doğrultusunda eğitim programlarını gözden geçirip geliştirmeleri; olmayan bölümlerin bu konuda oluşturacakları programları tüm eğitim yıllarına yayacak şekilde müfredatın bir parçası haline getirmeleri,

2. Üniversiteye yeni başlayan birinci sınıf öğrencilerinin sağlıklı yaşam davranışlarını değerlendiren tanımlayıcı araştırmaların yapılması, bu araştırmaların sonucunda bireysel destek verilmesi gereken öğrencilerin saptanması ve bu öğrencilere yönelik programlar oluşturulması,

3. Sağllk bilimleri öğrencilerine sağlıklı yaşam davranışlari ile ilgili materyaller hazırlattırılması, bu konuda diğer fakültelerde okuyan öğrencilere "akran eğitimi” yapmalarını sağlayacak programlar oluşturulması,

4. Kampus içerisinde sağlıklı yaşam davranışlarını destekleyecek çalışmaların yapılması ve var olanların geliştirilmesi,

5. Üniversiteye adaptasyon sürecinde ve sonrasında danışmanlık ve rehberlik hizmetlerinin etkin şekilde uygulanmas1,

6. Ayrıca, özellikle diğer bölümlere göre tüm ölçek puanları daha düşük çıkan tıp fakültesi öğrencilerine yönelik planlamalarda, uzmanlık eğitim müfredatında "sağlığı geliştirme danışmanlı̆̆ı" bulunan Aile Hekimliği disiplini ile işbirliği yapılması, hem tıp fakültesi öğrencilerinin hem de aile hekimliği uzmanlık öğrencilerinin eğitimlerine katk1 sağlayacaktır.

Bu çalsşma İstanbul'da 22-25 Ekim 2015 taribinde gerceklessen "20th WONCA Europe Conference" kapsaminda poster bildiri olarak sunulmus ve Turkish Journal of Family Practice Special Isune Volume 19, p16. Keynote lectures and selected abstracts presented at the 20th WONCA Europe Conference, İstanbul, (2015) özel sayzsında özet olarak yaymlanmıștır

*Bu çalısma, "Tipta Uzmanllk Tezi”" kapsaminda, 
Cukurova Üniversitesi Bilimsel Arastirma Projeleri Birimi tarafindan TF2009LTP27 proje numarast ile desteklenmiștir.

\section{KAYNAKLAR}

1. Özvarış ŞB. Sağlık eğitimi ve sağlığ geliştirme. In Halk Sağlığ1 Temel Bilgiler (Eds Ç Güler, L Akın):1132-6 Ankara, Hacettepe Üniversitesi Yavinlari. 2006.

2. McWhinney IR, Freeman T. Textbook of Family Medicine, 3rd ed., New York, Oxford University Press. 2009.

3. Ferguson KJ. Health behaviour. In Public Health \& Preventive Medicine. 14 th ed. (Ed. RB Wallace):8116.. Stanford: Appleton\& Lange; 1998.

4. Fleming P, Marshall G. Lifestyle interventions in primary care. Systematic review of randomized controlled trials. Can Fam Physician. 2008;54:170613.

5. Hash RB, Munna RK, Vogel RL, Bason JJ. Does physician weight affect perception of health advice? Prev Med. 2003;36:41-4.

6. Oberg EB, Frank E. Physicians' health practices strongly influence patient health practices. J R Coll Physicians Edinb. 2009;39:290-1.

7. Centers for Disease Control and Prevention. Improving the Health of Adolescents \& Young Adults: A Guide for States and Communities. Atlanta, GA, Centers for Disease Control and Prevention 2004.

8. Can G, Özdilli K, Erol Ö, Unsar S, Tulek Z, Savaşer $S$ et al. Comparison of the health-promoting lifestyles of nursing and non-nursing students in Istanbul, Turkey. Nurs Health Sci. 2008;10:273-80.

9. Zaybak A, Fadıloğlu Ç. Üniversite öğrencilerinin sağlığ1 geliştirme davranışı ve bu davranışı etkileyen etmenlerin belirlenmesi. Ege Üniversitesi Hemşirelik Yüksek Okulu Dergisi. 2004;20:77-95.

10. Ayaz S, Tezcan S, Akıncı F. Hemşirelik yüksekokulu öğrencilerinin sağlı̆̆ geliştirme davranıșları. Cumhuriyet ÜniversitesiHemșirelik Yüksek Okulu Dergisi. 2005;9:26-34.

11. Celik GO, Malak AT, Bektas M, Yılmaz D, Yümer AS, Öztürk $Z$ et al. Sağllk yüksekokulu öğrencilerinin sağlığı geliştirme davranışlarını etkileyen etmenlerin incelenmesi. Anadolu Tibbi Araştırmalar Dergisi. 2009;3:164-9.

12. Ünalan D, Şenol V, Öztürk A, Erkorkmaz Ü. Meslek yüksekokullarının sağlık ve sosyal programlarında öğrenim gören öğrencilerin sağlıklı yaşam biçimi davranışları ve öz-bakım gücü düzeyleri arasındaki ilișkinin incelenmesi. İnönü.ÜniversitesiTip Fakültesi Dergisi. 2007;14:101-9.

13. Yıldırım N. Üniversite öğrencilerinin bazı sosyodemografik özelliklerinin sağlıklı yașam biçimi davranışlarına etkisi. (Yüksek lisans tezi). Sivas,
Cumhuriyet Üniversitesi, 2005.

14. Cihangiroğlu Z, Deveci SE. Fırat Üniversitesi Elazığ Sağlık Yüksekokulu öğrencilerinin sağlıklı yaşam biçimi davranışları ve etkileyen faktörler. Fırat Tip Dergisi. 2011;16:78-83.

15. Tuğut $N$, Bekar M. Üniversite öğrencilerinin sağllğ1 algılama durumları ile sağlıklı yaşam biçimi davranışları arasındaki ilişki. Atatürk Üniversitesi Hemșirelik Yüksekokulu Dergisi. 2008;11:17-26.

16. Ay S, Yanikkerem E, Calim SI, Yazici M. Healthpromoting lifestyle behaviour for cancer prevention: a survey of Turkish university students. Asian Pac J Cancer P. 2012;13:2269-77.

17. Şimşek H, Öztoprak D, İkizoğlu E, Safalı F, Yavuz Ö, Onur Ö et al. Tip fakültesi öğrencilerinde sağlıklı yaşam biçimi davranışları ve ilişkili etmenler. Dokuz Eylül Üniversitesi Tip Fakültesi Dergisi. 2012;26:151-7.

18. Nacar M, Baykan Z, Cetinkaya F, Arslantas D, Ozer A, Coskun $\mathrm{O}$ et al. Health promoting lifestyle behaviour in medical students: a multicentre study from Turkey. Asian Pac J Cancer P. 2014;15:8969-74.

19. Peker K, Bermek G. Predictors of health-promoting behaviors among freshman dental students at Istanbul University. J Dent Educ. 2011;75:413-20.

20. Hacihasanoglu R, Yıldırım A, Karakurt P, Saglam R. Healthy lifestyle behaviour in university students and influential factors in eastern Turkey. Int J Nurs Pract. 2011;17:43-51.

21. Karadeniz G, Uçum EY, Dedeli Ö, Karaağaç Ö. Üniversite öğrencilerinin sağlıklı yaşam biçimi davranışları. Türk Silahlı Kuvvetleri Koruyucu Hekimlik Bülteni. 2008;7:497-502.

22. Altun İ. Effect of a health promotion course on health promoting behaviours of university students. East Mediterr Health J. 2008;14:880-7.

23. Coban A, Kavlak O, Özbasaran F. The evaluation of school of health students' knowledge and behavior of healthy life-styles of related to importance to prevent cancer. Asian Pac J Cancer Prev. 2010;11:773-6.

24. Walker SN, Sechrist KR, Pender NJ. The Health Promoting Lifestyle Profile development and psychometric characteristics. Nurs Res. 1987;36:7680.

25. Bahar Z, Beșer A, Gördes N, Ersin F, Kıssal A. Sağlıklı yaşam biçimi davranışları ölçeği II'nin geçerlik ve güvenirlik çalışması. Cumhuriyet Üniversitesi Hemsirelik Yüksekokulu Dergisi. 2008;12:1-12

26. Diez SMU, Perez-Fortis A. Socio-demographic predictors of health behaviors in Mexican college students. Health Promot Int. 2010;25:85-93.

27. Stark MA, Manning-Walsh J, Vliem S. Caring for self while learning to care for others: a challenge for nursing students. J Nurs Educ. 2005;44:266-70.

28. Wei CN, Harada K, Ueda K, Fukumoto K, Minamoto K, Ueda A. Assessment of health- 
promoting lifestyle profile in Japanese university students. Environ Health Prev Med. 2012:17:222-7.

29. Bottorff JL, Johnson JL, Ratner PA, Hayduk LA. The effects of cognitive-persceptual factors on health promotion behavior maintanence. Nurs Res.
1996;45:30-6.

30. Savc1 S, Öztürk M, Arrkan H, İnce Dİ, Tokgözoğlu L. Üniversite öğrencilerinin fiziksel aktivite düzeyleri. Türk Kardiyol Dern Arş. 2006;34:166-72. 